\title{
INTERCULTURAL COMMUNICATION: HOW PATTANI STUDENTS COMMUNICATE TO KEMBANGARUM RESIDENTS
}

\author{
Muhammad Nuryanto \\ Institut Agama Islam Negeri Salatiga
}

\begin{abstract}
The research aimed to examine (1) the anxiety experienced by Pattani Students when they first mingled with Kembangarum residents, (2) the anxiety management used by Pattani Students, (3) the model of intercultural communication between Pattani students and Kembangarum residents. The type of the research used in this study is a case study. While the approach was qualitative approach. Data collection techniques used were in-depth interviews and participatory observation. The subject of the study is Pattani students and Kembangarum residents. The findings showed there was a cultural shock experienced by Pattani students when they first lived in Kembangarum. The cultural shock resulted in anxiety and uncertainty when they communicate with the locals. To overcome this anxiety, Pattani students used Gudykunst's three anxiety management, including the self-concept, motivation and, reaction to the locals. The communication model used by Pattani students was intercultural approaches by prioritizing dialectics and interpretation of community behavior.
\end{abstract}

Keyword: Intercultural Communication, Anxiety Management, Pattani Students

\section{INTRODUCTION}

Everyone who lives in society will dissolve and live in the culture of the group. This often became a problem with each individual's personality. Interactions with other groups are needed. From this interaction, each group will discover a new culture and the clash is most likely unavoidable. This happens because each group tends to maintain its own culture.

A Society with their thoughts and perceptions favor what they have and demean other groups. Taking into consideration a relationship, each group needs to make a relationship or interaction with other groups. It aims to develop group knowledge in various fields. Based on the clashes that occur in the future, this is the task of the society and their respective members to take suitable action.

Samovar et al., (2010) conveyed those three main elements shape cultural perceptions and have a large or direct influence on individual participants in intercultural communication. First is the world view (belief system or religion, cultural values, and behavior), second is a symbol system (verbal and non-verbal), and third is a social organization (family and institution). To understand the world, the values and behaviors of others we must understand the framework of perception. In ideal intercultural communication, we expect a lot of similarities in cultural experiences and perceptions. But the cultural character tends to introduce us to experiences that are different. Therefore he brings different cultural perceptions to the world outside his own culture. 


\section{ELLITE}

Journal of Education, Linguistics, Literature and Language Teaching

Liliweri (2012) added that intercultural communication would be memorable if everyone involved in the communication process was able to place and function communication in a particular cultural context. Besides, intercultural communication is very much determined by the extent to which humans can reduce misunderstandings made by intercultural communicators and communicants.

Starting in 2014 IAIN Salatiga and Azizstan Foundation School of Pattani Thailand have established cooperation between the two in the field of education. Dozens of Pattani Students attend IAIN Salatiga who lives in Kembangarum. These students will be the informants in the study. The existence of Pattani students in Salatiga especially in Kembangarum, they bring their own culture, and its culture meets the local culture of Kembangarum. The reason for choosing this location is because Pattani Students of IAIN Salatiga all live in Ma'had Al Jami'ah located in Kembangarum. This meeting needs to be given attention, in order not to cause a huge culture shock and even to make rejections on a small or large scale. As Liliweri (2012) added that every human being with or without an organization or group, they must put one of his feet on the other world. It aims to be responsive and follow the demands of the era of the advancement of human civilization. To carry out this intercultural interaction communication must be used so that it can bridge the relationship between people or society with different cultures. As we know, relationships that involve differences in individual backgrounds are included in the interaction.

The presence of Pattani students in Kembangarum brings problems related to their interaction with the locals. One of them is communication problems due to cultural differences, language, and the style of communication between both two. Since there are new cultures those are quite different from theirs, this problem needs to be examined in term of their cultural communication. Between the two (Pattani students and the locals) they try to accommodate it, to gain a new understanding. That was the reason why the writer was interested in the current topic, and the writer believes that it needs to be examined in the framework of intercultural communication. Besides, new findings could be gained to be provided and beneficial for each individual who entered into the new environment.

Moreover, Sihabudin (2011) defined that it is important to discuss why intercultural communication in the contemporary era required every individual to understand the dynamics of life in various fields and related to mobility. The need to move to other regions and countries requires knowledge of other cultures from each region or visited country. Researching intercultural communication is important to share different cultures. This exchange of culture, or rather share can add to the cultural insights of each individual or group and organization so that there is no ongoing culture shock.

As an early finding of this study, the writer found that communication took place between Pattani students of IAIN Salatiga and the local people of Kembangarum. At the beginning of their presence in Salatiga, where they lived in Ma'had Al Jami'ah located in Kembangarum, Salatiga. What they say if they need something from their friends and residents around, is just using simple language equipped with symbols, pointing, and nodding as a communication tool. This is their initial communication as strangers. They have a communication limit on language ability. They feel alienated and uncertain about the attitude that will be taken to communicate. Therefore, the writer thinks that the need to conduct this study by considering that there should be a clear model related to the communication of foreigners with the communities where they live temporarily as a tool for adaptation and interaction between cultures. Many studies have been conducted dealing with the current theme, which only examined the model of intercultural communication from one side. The novelty offered in the present study is an intercultural 
ELLITE

Journal of Education, Linguistics, Literature and Language Teaching

communication model resulted from the management of anxiety experienced by migrants in an area and we also examined two groups at once, namely Pattani students as foreigners and Kembangarum residents.

\section{LITERATURE REVIEW}

\subsection{INTERCULTURAL COMMUNICATION}

It will be more comfortable interacting or communicating with our group of people who have similarities with us in the form of tastes, meanings, thoughts, beliefs, and even culture. This comfort is dealing with people of the same background, we could say as a comfort zone as stated by Pearson, et al., (2016). But the circumstances sometimes force us to leave our group, for various reasons. It possible for everyone to deal with people of different backgrounds? For instance, when someone feels comfortable with the space of others, it will be difficult for him to be able to interact and communicate with people who have differences from him. For example, someone who used to communicate using his native language and never deals with another language. When he met people who have different backgrounds, he will be surprised that cause obstacles in communication in the language framework.

William in Liliweri (2004) dfined that the study of intercultural communication can be said to emphasize the effect of culture on communication. As a result, there is a relationship between communication and culture. He added that the study of intercultural communication can be said to emphasize the effect of culture on communication. As a result, there is a relationship between communication and culture. Andrean in Samovar, et. Al. (2010) interpret intercultural communication as communication between people who have different backgrounds. This communication occurs with the meetings in the social space. Where the space is indeed possible the occurrence of cultural differences and the establishment of communication.

Besides, Chen, G. M., \& Starosta, W. J. (2005) added that intercultural communication is a symbolic system exchange or negotiation process. What is meant by these two figures is that communication occurred between people of different cultures, given each other information and required interpretation. This is called the symbolic exchange system. By then influencing the attitude of the people involved in the exchange. This is what can limit and guide human behavior in the future

In defining intercultural communication, we certainly will not be separated from the model that is owned by this communication. Existing communication models can help us map the course of communication. Besides, the model can make it easier for us to explain the phenomena that occur. The following basic models of intercultural communication: 


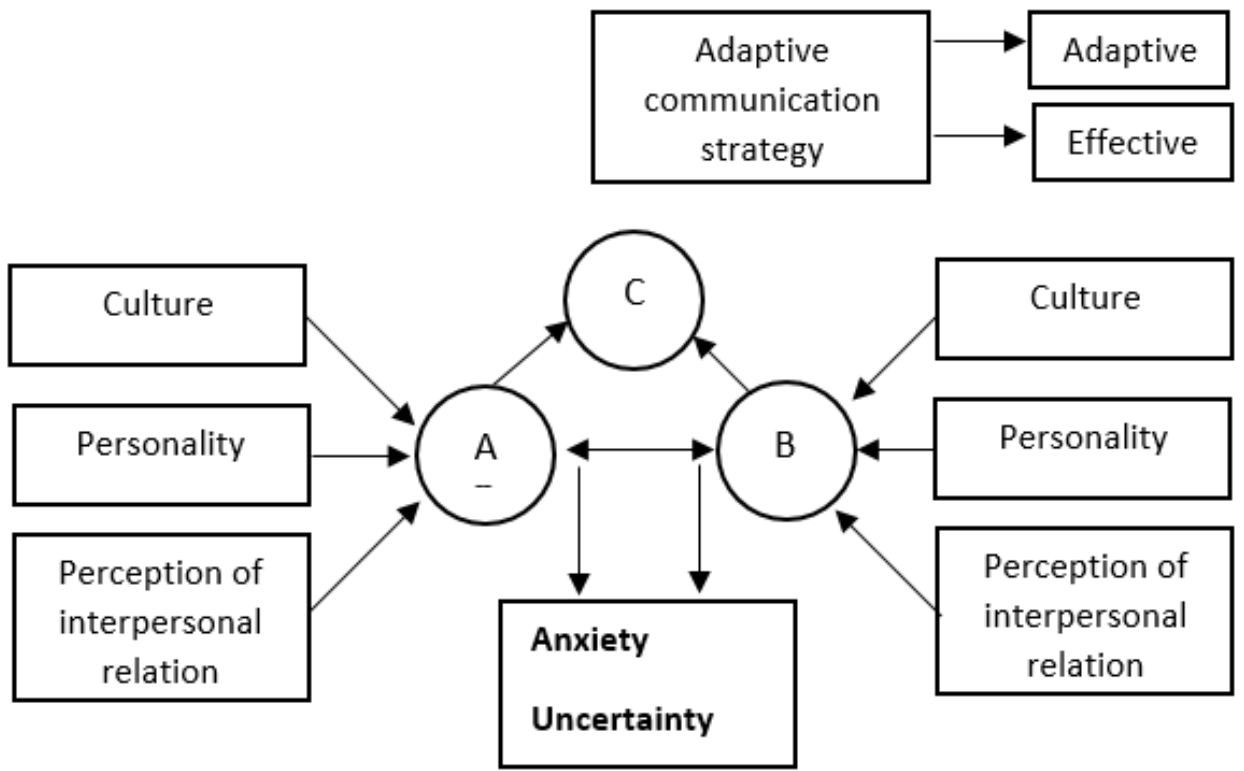

Figure 1. Basic Model of International Communication

From the communication model above, the exchange or relationship between culture A and culture B can produce a new culture that is culture C, in the course of this relationship or interaction, the important thing to note is the communication made and the symptoms that appear in it. First are uncertainty and anxiety, which arise from the suspicion of others with minimal ability to predict others. Also, the lack of predictive ability will cause uncertainty to behave. Second, accommodating communication. In intercultural communication that we do, we must be able to adjust to others who enter into ongoing intercultural communication. Why does it require adaptation? Our ability to understand others and succeed in predicting them requires exploration. Chen, G. M., \& Starosta, W. J. (2005)

Moreover, Liliweri (2012) also conveyed that this assessment is carried out on adaptation or adjustment. From the adaptations that have been made, we can understand and predict others. Then, from this adaptation effective, communication could be acquired. With the provisions of each want to accommodate themselves to be open and adjust.

\subsection{THEORIES OF ANXIETY MANAGEMENT}

Gudykunst (2004) in is theory focused on cultural differences between internal groups and foreign groups. This theory rested on its application in various situations. Where the difference between people who spread doubts and fears. He assumed that at least one of the people in the intercultural meeting was a foreigner. Through various crises initially, the stranger experienced anxiety and uncertainty. As a result, they feel uncomfortable and are unsure of how to behave.

Other experts use the terms accuracy, fidelity, and understanding. Otherwise Gudykunst (2004) used the term effective communication to minimize ignorance or misunderstanding. Griffin (2003) in this connection, he provides an effective communication model within the framework of intercultural communication through this theory. 


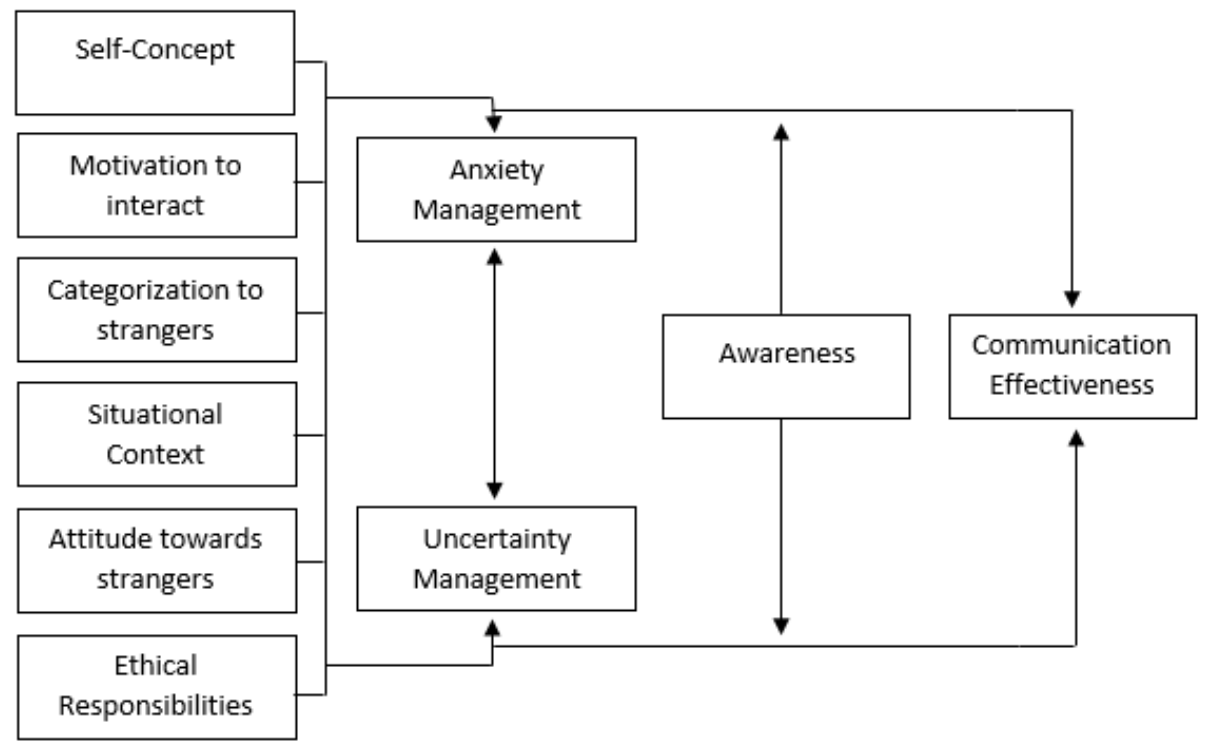

Figure 2. Basic Components of AUM Theory (Griffin, 2003, p. 429)

Based on the figure, starting from the left to the right is a sequential process. The righthand figure is the final destination. The figure to the left is the cause of misunderstanding in intercultural meetings that causes anxiety and uncertainty would be explained later. Previously, in this theory to acquire effective communication in a meeting of strangers and internal groups is to control two things that are nearly identic. Namely the uncertainty and anxiety.

Griffin (2003) added, before entering into the cause of the misunderstanding, it is worth discussing awareness. Based on this theory, awareness is the way in which inner groups and strangers can reduce their anxiety and uncertainty to the maximum level. Borman, et al., (2017) offered four levels of communication competence. First, the unconscious inability, means we misinterpret other people's behavior and never realize what we are doing. Second, the inability to be conscious, we know and aware that we misinterpret other people's behavior but do nothing. Third, the ability to consciously, we think about communication and continually try to change what we do to be more effective. Fourth, unconscious ability, we develop communication skills where we no longer think about how we talk and listen.

\subsection{CAUSE OF ANXIETY AND UNCERTAINTY IN INTERCULTURAL COMMUNICATION}

From the concept of the causes of anxiety and uncertainty in this theory, Griffin (2003) explained in the form of axioms or strong statements without the need for proof. The first is self-concept, increasing our self-esteem ability will decrease our anxiety and uncertainty and increase our ability to predict the behavior of others. Motivation to interact is also included as one of the Anxiety and Uncertainty causes in intercultural communication. Increasing confidence in our ability to predict the behavior of strangers will reduce our anxiety and uncertainty; the decrease will increase our confidence to predict other people's behavior. The third is our attitude towards strangers, the increase of our ability to process the complexity of strangers' information will reduce our anxiety and uncertainty and increase our ability to accurately predict the behavior of others. 


\section{ELLITE}

Journal of Education, Linguistics, Literature and Language Teaching

Griffin (2003) added that increased self-similarity that we feel between ourselves and strangers will reduce anxiety and uncertainty and increase our ability to accurately predict the behavior of others. It also deals with the situational processes, the increasing of the power that we feel we are no more than strangers will reduce anxiety, and uncertainty and the accuracy of predicting the behavior of people. Finally, the closeness with strangers and ethical responsibilities is also becoming a major cause of anxiety and uncertainty, since increasing our attractiveness to strangers will reduce anxiety and uncertainty and increase our confidence in predicting other people's behavior.

\subsection{THE ELEMENTS OF COMMUNICATION}

Mulyana (2007) defined the elements of communication are as follows:

- Message

The message referred to something that communicator sent to the communicant. Messages can be delivered face to face or through communication media. Its contents can be in the form of science, entertainment, information, advice, or propaganda.

- Communicator

Communicators are people who have a motive for communication or who aim to share or spread information or messages.

- Communicant

The communicant is the one that is being targeted by the communicator. The communication can consist of one or more people, it can be in the form of groups, parties or countries. This means that it is an important element in communication because he is the target of communication. If a message is not received by the communicant, it will cause various kinds of problems that often require changes, whether at the source, message, or the media.

- Media

The media is referred to as a tool used to move messages from the source to the recipient. There are several opinions regarding channels or media. Some think that the media can take many forms, for example in interpersonal communication the senses are considered as communication media. In addition to the human senses, there are also communication channels such as letters, telephones, telegrams, and any other tools.

- Effect

The effect is the difference between what the recipient thinks, feels, and does before and after receiving the message. Influence can be interpreted as a change or strengthening of belief in one's knowledge, attitudes, and actions as a result of receiving messages.

\section{METHODOLOGY}

The type of research used in this study is a case study. While the approach used in this study is a qualitative approach, which is a research procedure that produces descriptive data in the form of words in written and oral form from individuals and observed behavior as stated by Sugiyono (2013). According to Taylor, et. al. (2015), this approach is directed at an individual background holistically. Consequently, the researcher does not isolate the research subject in a particular hypothesis or theory by default but views some of the needs.

Data collection techniques used in the current study were participatory observation and in-depth interviews. The researchers conducted participatory observation to collect the data on 


\section{ELLITE}

Journal of Education, Linguistics, Literature and Language Teaching

how Pattani Students communicates with the local. As well as an in-depth interview conducted to gain deeper data on it. The subjects of this study were Pattani Students of IAIN Salatiga who were living in Kembangarum and Kembangarum Citizens. The sample selection of Pattani students was done carefully, in which selected students have their uniqueness. Miles, et al. (2013) figured that data analysis is conducted based on an interactive analysis model consisting of three main components namely data condensation, data display, and conclusion drawing/ verification. Based on this model, the three components are not linear processes but are cycles. That is, all data obtained by researchers conducted the selection and grouping of data. Data that is assessed as inappropriate is discarded as a data reduction process. While the corresponding data is retained as a data serving process for the drawn conclusions. Nevertheless, this process does not stop at this stage, to get a valid conclusion, it is possible to reduce and represent the data.

\section{FINDINGS AND DISCUSSION}

\subsection{ANXIETY FACED BY PATTANI STUDENTS OF IAIN SALATIGA TOWARDS LOCAL PEOPLE OF KEMBANGARUM}

Intercultural communication becomes a very important study in societies that has different backgrounds and cultures. Communication is needed to create harmony among people who have different cultural backgrounds when interacting with each other. In this study, the authors conducted in-depth interviews with Pattani students of IAIN Salatiga in Kembangarum and interviews with Kembangarum residents. The researcher found several facts about what happened to the Pattani students when they first arrived in Kembangarum.

"The first time I came here, I was surprised because there are so many cultural differences here and in Pattani. Although we are used to speak Malay, Indonesian is completely different. The local people are so friendly to us, when they meet us they always through us a smile, but we foreigners were fell weird with that act" (Interview, ID, February $23^{\text {rd }}, 11.45$ )

They experienced a deep cultural shock due to culture differences between Pattani and Kembangarum. The first time Pattani students were confused by the familiarity of Kembangarum residents who were friendly and smiling, shaking hands between men and women, which they did not find it in Pattani. Fawaas Tilee the second semester Pattani student said that there are so many things that are different from our culture in Kembangarum, men, and women shaking hands with each other. Everyone smiled at us, not a few also gave strange looks to us. It's different from our culture in Pattani.

"We see men and women shaking their hands each other, it's so weird for us, we couldn't find it in Pattani, hehe" (Interview, FT, February $23^{\text {rd }}, 11.00$ )

The above problem is also supported by the fact that the writer found when joining participatory observations. Many Pattani students did not understand when interacting with Kembangarum residents or students. The residents of Kembangarum need to express the message to be conveyed several times followed by gestures and symbols as a tool.

The problems faced by Pattani students become increasingly complex when they realize that diversity in Kembangarum is very complex, where they are not only surprised by one type of culture and communication patterns but many cultures and communication models that exist in Kembangarum. As we know, there are a lot of newcomers in Kembangarum. 
"There're cultures in Kembangarum. The way we interact and communicate with local people is becoming more difficult since there are many citizens from various regions." (Interview, FT, February $23^{\text {rd, }} 11.00$ )

Sutomo, the local people of Kembangarum added that Pattani students who live here, have difficulties when interacting and communicating with our citizens. Because we have a lot of types of citizens and are composed of various cultural backgrounds.

With the cultural shock experienced by Pattani students in Kembangarum, they experienced anxiety and fear in communication. From the data collected by researchers from our interview activities to Pattani students living in Kembangarum, researchers found anxiety experienced by Pattani students at Salatiga IAIN in Kembangarum as they are afraid they do not understand what message from the people of Kembangarum wants to convey. Otherwise, as communicators, they are afraid that they would not be able to convey a message when communicating with Kembangarum Residents.

\subsection{ANXIETY MANAGEMENT USED BY PATTANI STUDENTSS OF IAIN SALATIGA TOWARDS KEMBANGARUM RESIDENT}

Pattani students use several anxiety management strategies to overcome the anxiety problems they faced. The main factor that makes the anxiety that occurs in Pattani students is self-concept. Increasing our self-esteem inability will result in a decrease in our anxiety and uncertainty and an increase in our ability to predict the behavior of others. The lack of selfconcept that Pattani students when they first came to Salatiga caused anxiety in communicating with residents of Kembangarum, Salatiga. From the observation in social life and the adjustment process of Pattani students in adapting to the Kembangarum environment found that they were trying to ask other students and fellow friends from Pattani who had been previously studied at IAIN Salatiga and lived in the Kembangarum. They try to understand their self-concept and try to understand how Kembangarum's culture was. This made it easy to interact and adapt to languages. Ismaal Dereh said that when they first came here, they stayed with another Pattani who first studied at IAIN Salatiga so that they could ask and try to find out how the culture and how to interact with Kembangarum residents and learn how they should behave.

"When I first came to Indonesia I lived in Ma'had Al Jami'ah (Kembangarum) along with older Pattani students who had already arrived before, and I was told to live in the same room with our seniors from Pattani. At first, I couldn't talk to our local roommates, I can only smile and talk to my Pattani colleges and I started to ask them the meaning of some Indonesian phrases, then later I tried to speak with the locals" (Interview, ID, February $23^{\text {rd }}$, 11.45)

Motivation to interact is also a way to manage anxiety carried out by Pattani students. Increased confidence ability to predict the behavior of strangers will reduce our anxiety and uncertainty; the decrease will increase our confidence to predict other people's behavior. Ismaal Dereeh added:

"When we came, we tried to understand how was the life and social interactions carried out by residents of Kembangarum. We began to translate how they communicate, both verbally and non-verbally. We ask our roommate (nonPattani students), what do you mean by this? What does it mean? Our motivation 
ELLITE

Journal of Education, Linguistics, Literature and Language Teaching

to interact with Kembangarum residents is also high since we need information from them. Otherwise, we need to deliver and send messages to them." (Interview, ID, February $23^{\text {rd }}, 11.45$ )

How students respond and react to strangers (Kembangarum residents) is also an anxiety management strategy used by students of Pattani IAIN Salatiga. They learn to react to what Kembangarum residents give to them. From interviews conducted by researchers, we know that Pattani students are trying to give a reaction and response to the behavior of Kembangarum residents. Every citizen of Kembangarum who met Pattani students only smiled at them, initially they did not understand the meaning of the smile. Then Pattani students began to get to know and learn to smile with otherwise. Pattani students began to get used to the strange gaze of Kembangarum residents during the early weeks in Kembangarum, but after starting to see the situation of Kembangarum residents in the surrounding environment, Pattani students also realized that everyone greeted each other with a smile when they met. As explained by Anwa Chelap:

"At first we were confused, why did everyone smile on us? Then we realized that smiling is a way for Kembangarum residents and Salatiga community, in general, to show hospitality to everyone including us foreign students. After that, if someone smiled at us we would respond it with another smile" (Interview, AC, February $23^{\text {rd }}, 11.50$ )

Sutomo added, he said that his citizens are friendly, if they meet any one, it will show a friendly attitude, smile, greet, etc. Not only with Pattani students but also foreigners who live here, there are European, Americans, Koreans, Papuans, etc., initially they were awkward, now they are accustomed.

\subsection{MODEL OF COMMUNICATION USED BY PATTANI STUDENTS OF IAIN SALATIGA TOWARDS KEMBANGARUM RESIDENTS} residents.

The need to deliver or find a message required us to interact with the Kembangarum

"The topics of conversation are different from the topic they used to discuss with Indonesian students on the campus, which is about lecturing material. Conversation and communication with Kembangarum residents take place in a simple context. Such as conversations with food stall owners, photocopier owners, online motorcycle taxi drivers, mosque worshipers, and others" (Interview, AC, February $23^{\text {rd }}, 11.50$ )

Sugeng Basuki the Muslim leader in Kembangarum said that Pattani Students often interact with the locals, even though the interactions are very simple as well as they greet us, otherwise. This is reinforced by the findings of observations made by researchers. They tend to close themselves with Indonesian students and local people of Kembangarum, if they have to interact they talk about very simple things.

As communicator, Pattani students prioritize dialectics and interpretation of community behavior. Then they find out how they should act, or what should be started when making a contact with local people of Kembangarum, there were in terms of customs, manners, and order especially about how they communicate normally. They deliver messages to the communicant by preparing what they want to say. Anwa Chelap stated that firstly he saw and observed how citizens behave, then he interpreted it before he tried to behave according to the 


\section{ELLITE}

Journal of Education, Linguistics, Literature and Language Teaching

interpretation of the cultural communication framework he saw. When he wants to talk to the people around him, he always prepared first the topic and also the language and vocabulary that we will convey. The communication model above is an intercultural communication model used by Pattani students communicating with Kembangarum residents. When the researchers observed Pattani students toward Kembangarum residents, several things were discovered by the writer. Among the findings are the language used, accent, or way of communicating with the interlocutors, the use of standard and non-standard Indonesian words in communication. Muhammadmomdon Wamu added:

"We always speak and communicate in standard Indonesian language, like what we learned in pre-class activities, as far as we can. If they do not understand, we will repeat it and even accompanied by body language (while practicing)" (Interview, MW, February $23^{\text {rd }}, 11.30$ )

There is an effort to understand the culture and language of Kembangarum residents. Therefore they try to increase their vocabulary by reading a dictionary or using a translator. As Romdon wamu explained that when they want to talk to the people they usually open the translator. They also open the dictionary at their leisure to increase vocabulary mastery.

They experienced difficulties when they become interlocutors of Kembangarum residents. Especially when people use unstandardized Indonesian language or even with a mixture of Javanese. Anwa Chelap said that it was difficult for them since the people spoke unstandardized Indonesian or even local languages.

Based on the observations made by researchers, the researchers discovered the fact that when Pattani students did not understand what was conveyed by Kembangarum residents, they asked him to speak slowly and use other words, which has the same meaning. Ismail Dereh stated that if the people speak too fast, they ask them to repeat it slowly and use standard language, with other similar words that we understand, sometimes this also becomes a bridge for us to exchange languages and vocabularies.

There is not too much media used by Pattani students to communicate with Kemabagarum residents, they only communicate directly. This has something to do with the message they want to convey to citizens and vice versa are just simple things. Romdon Wamu said that they do not use any media to talk with the people, they just talk directly.

It's mean that intercultural communication is not yet a bridge of communication for them. But intercultural communication over time can help to communicate freely and can be understood by each other. There are several reasons why the communication between Pattani students and local people of Kembangarum work are as follows: first is the proximity between Pattani students and Kembangarum residents. And then the high intensity of communication with residents of Kembangarum also became a major reason. And the most important is the understanding between Pattani students and Kembangarum residents.

\section{CONCLUSIONS}

Based on the results of the analysis that the researcher did in this current study. The conclusion was that there was a cultural shock experienced by Pattani students when they first lived in Kembangarum, Salatiga. The cultural shock results in anxiety and uncertainty when communicate or interact. To overcome this anxiety, Pattani students used Gudykunst's three anxiety management, those are deepened their self-concept, motivation to interact, and how to react to strangers. The success of Pattani students in communicating with local people of Kembangarum achieved by conducting anxiety management. 
ELLITE

Journal of Education, Linguistics, Literature and Language Teaching

The communication model used by Pattani students can be seen from the five elements of communication which reflect the use of intercultural approaches by prioritizing dialectics and interpretation of community behavior. Through this approach Pattani students learn and try to translate the behavior of Kembangarum residents to be followed up with their behavior towards residents. Their desire to know more about the characteristics of citizens became the major tool that supports their success in communication.

With the above approach, Pattani students can manage anxiety in intercultural communication, as well as interpersonal communication. That is, if they already know how to behave, or what should be started when making contact with Kembangarum residents, both within the framework of customs, manners, order as well as the usual language used in the Kembangarum.

While the output obtained by Pattani students through their intercultural communication with Kembangarum residents is the formation of understanding of each side. The clear definition referred to the intercultural framework and differences in background. This understanding is built on the need to bind Pattani students to continue to have good relations with residents. That understanding could also be said as a social status held by Pattani students. Furthermore, the developed understanding brought them to be able to enter into previously difficult accesses, both information and social-community.

\section{REFERENCES}

Bormann, E. G., \& Shapiro G. L. (2017). Interpersonal Communication In The Modern Organization. New York: Andesite Press.

Chen, G. M., \& Starosta, W. J. (2005). Foundations of Intercultural Communication $\left(1^{\text {st }} \mathrm{ed}\right)$. Lanham: Rowman \& Littlefield Publishing Group Inc.

Griffin, E. (2003). A First Look at Communication Theory. Boston: Mc Graw Hill.

Gudykunst, W. B., \& Kim, Y. Y. (1992). Communicating with Strangers: An Approach to Intercultural Communication ( $4^{\text {th }}$ ed). Boston: McGraw-Hill.

Gudykunst, W. B. (2004). Theorizing About Intercultural Communication. Thousand Oaks: SAGE.

Liliweri, A. (2012). Intercultural Communication . Jurnal Ilmu Komunikasi, 10 (1), 15-16.

Miles, M. B., Huberman, A. M., \& Saldana, J. (2013). Qualitative Data Analysis: A Methods Sourcebook (3rd ed). Thousand Oaks: SAGE Publications, Inc.

Mulyana, D. (2007). Ilmu Komunikasi Suatu Pengantar. Bandung : Remaja Rosdakarya.

Pearson, J. C., Nelson, P. E., Titsworth, S., \& Hosek, A. M. (2016). Human Communication $\left(6^{\text {th }}\right.$ ed). Mc Hill: McGraw-Hill Education.

Samovar, L. A., Porter, R. E., \& McDaniel, E. R. (2010). Communication Between Culture (7th ed). Boston: Wadsworth. 
ELLITE

Journal of Education, Linguistics, Literature and Language Teaching

Sihabudin, A. (2011). Komunikasi AntarBudaya; Satu Perspektif Multidimensi. Jakarta: Bumi Aksara.

Sugiyono. (2013). Metode Penelitian Kuantitatif Kualitatif dan R\&D. Bandung: Alfabeta.

Taylor, S. J., Bogdan, R., \& DeVault, M. L. (2015). Introduction to Qualitative Research Methods: A Guidebook and Resource $\left(4^{\text {th }}\right.$ ed). New Jersey: John Wiley \& Sons.

\section{Interview Sources}

Dereh, Ismaal. (2020, February 23rd). Personal Interview.

Tilee, Faawas. (2020, February 23rd). Personal Interview.

Chelap, Anwa. (2020, February 23rd). Personal Interview.

Wamu, Muhammadromdon. (2020, February 23rd). Personal Interview.

Sutomo. (2020, February 25th). Personal Interview.

Basuki, Sugeng. (2020, February 27th). Personal Interview. 